\title{
Owenweeksia hongkongensis gen. nov., sp. nov., a novel marine bacterium of the phylum 'Bacteroidetes'
}

Correspondence

Madeline Wu

bomwu@ust.hk

\author{
Ken W. K. Lau, ${ }^{1}$ Connie Y. M. Ng, ${ }^{1}$ Jianping Ren, ${ }^{1}$ Simon C. L. Lau, ${ }^{1}$ \\ Pei-Yuan Qian, ${ }^{1}$ Po-Keung Wong, ${ }^{2}$ T. C. Lau ${ }^{2}$ and Madeline $\mathrm{Wu}^{1}$
${ }^{1}$ Department of Biology, The Hong Kong University of Science and Technology, Clear Water Bay, Kowloon, Hong Kong, S. A. R., P. R. China
${ }^{2}$ Department of Biology, The Chinese University of Hong Kong, Shatin, NT, Hong Kong, S. A. R., P. R. China

\begin{abstract}
An aerobic, Gram-negative, non-fermentative, rod-shaped, motile, orange-pigmented bacterium, UST20020801 ${ }^{\top}$, was isolated from sea-water samples collected from Port Shelter, Hong Kong, S.A.R., China, in August 2002. The full 16S rRNA gene sequence of this strain shared only $\mathbf{8 7 . 5} \%$ similarity with its nearest relative, Crocinitomix catalasitica, a species of the family Cryomorphaceae. However, strain UST20020801 ${ }^{\top}$ possessed menaquinone-6, a major respiratory quinone of members of the family Flavobacteriaceae. This strain contains unique fatty acids such as $115: 1 \mathrm{G}, \mathrm{i} 17: 1 \omega 9 c, 2-\mathrm{OH} 15: 0,15: 1 \omega 6 c$ and three unknown fatty acids of equivalent chain-length of $11.543,13.565$ and 16.582 . Further analysis of its ecophysiology and biochemistry suggests that this strain represents a new genus in the phylum 'Bacteroidetes'. The name Owenweeksia hongkongensis gen. nov., sp. nov. is proposed. The type strain is UST20020801 ${ }^{\top}\left(=\right.$ NRRL B-23963 $\left.{ }^{\top}=\mathrm{JCM} 12287^{\top}\right)$.
\end{abstract}

Members of the phylum 'Bacteroidetes' are important decomposers of high-molecular-mass organic matter in sea water (Cottrell \& Kirchman, 2000). Recently, the family Cryomorphaceae was proposed as a member of the phylum 'Bacteroidetes'. This family encompasses three genera, Brumimicrobium, Cryomorpha and Crocinitomix, which form a distinct clade in the class 'Flavobacteria', branching between the families Flavobacteriaceae and Bacteroidaceae (Bowman et al., 2003). Current members of the family Cryomorphaceae are psychrotolerant, rod- to filamentous-shaped and possess carotenoid pigments. They also require sea-water salts and complex organic compounds for growth (Bowman et al., 2003). In a study of the bacterial diversity in Hong Kong coastal sea water, a mesophilic, orange-pigmented, rod-shaped, moderately halophilic bacterium (strain UST20020801 ${ }^{\mathrm{T}}$ ) was isolated and characterized by polyphasic taxonomy. Analysis of the $16 \mathrm{~S}$ rRNA gene sequence confirmed that this bacterium was

Published online ahead of print on 3 December 2004 as DOI 10.1099/ ijs.0.63155-0.

The GenBank/EMBL/DDBJ accession number for the 16S rRNA gene sequence of UST20020801 ${ }^{\top}$ is AB125062.

Micrographs of Owenweeksia hongkongensis UST20020801 ${ }^{\top}$ and a phylogenetic tree based on 16S rRNA gene sequences showing the relationship between strain UST20020801 ${ }^{\top}$ and related taxa are available as supplementary material in IJSEM Online. affiliated to the family Cryomorphaceae in the 'Bacteroidetes'; sequence similarity with its nearest phylogenetic relative, Crocinitomix catalasitica, was $87 \cdot 5 \%$. On the basis of phenotypic and genotypic characteristics, fatty acid composition and phylogenetic position, it is proposed that strain UST20020801 ${ }^{\mathrm{T}}$ represents a novel species of a new genus, Owenweeksia hongkongensis gen. nov., sp. nov., of the family Cryomorphaceae in the phylum 'Bacteroidetes'.

Strain UST20020801 ${ }^{\mathrm{T}}$ was isolated from a sea-water sample collected from the outlet of a tank storing sand-filtered sea water that was pumped from a depth of $5 \mathrm{~m}$ adjacent to the Coastal Marine Laboratory of the Hong Kong University of Science and Technology. Aliquots of $100 \mu \mathrm{l}$ were spread onto agar plates containing YPS-SW medium $(0 \cdot 4 \%$ yeast extract, $0 \cdot 2 \%$ peptone, $1 \%$ starch, $75 \%$ sea water filtered through a $0.45 \mu \mathrm{m}$ filter and $1.5 \%$ agar) and incubated at $30{ }^{\circ} \mathrm{C}$ for 3 days. The isolate was cultivated aerobically on YP-SW medium (YPS-SW without starch), marine agar 2216 (Difco) or artificial sea water (ASW; $0 \cdot 1 \%$ $\mathrm{CaCl}_{2} .2 \mathrm{H}_{2} \mathrm{O}, \quad 0 \cdot 1 \% \mathrm{KCl}, \quad 0.5 \% \quad \mathrm{MgSO}_{4} .7 \mathrm{H}_{2} \mathrm{O}, \quad 0 \cdot 25 \%$ $\mathrm{NaCl}$ ) (Lewin \& Lounsbery, 1969) with $0 \cdot 4 \%$ yeast extract and stored at $-80{ }^{\circ} \mathrm{C}$ in YP-SW supplemented with $20 \%$ glycerol. Colony morphology was examined on YP-SW agar plates that had been incubated at $30^{\circ} \mathrm{C}$ for 5 days. Cell morphology under various growth conditions and gliding motility were elucidated by using an Olympus 
light microscope at $1000 \times$ magnification. Cell surface morphology was examined by scanning electron microscopy (Philips XL30) using a conventional method (Robinson et al., 1987). Gram-reaction was assessed according to Collins et al. (1989). The absorption spectrum of pigment extracted with $7: 3(\mathrm{v} / \mathrm{v})$ acetone:methanol was determined at $300-700 \mathrm{~nm}$ with a Beckman DU650 spectrophotometer. Bathochromatic shift test of flexirubin was performed by addition of $20 \% \mathrm{KOH}$ (Fautz \& Reichenbach, 1980 ). Growth was evaluated at various temperatures (4, $16,20,25,30,33,37,40$ and $42^{\circ} \mathrm{C}$ ) for up to 1 month in YP-SW broth. Growth at various $\mathrm{pH}$ values ( $\mathrm{pH} \mathrm{3 \cdot 0-10 \cdot 0)}$ was evaluated in YP-SW broth adjusted with $\mathrm{HCl}$ or $\mathrm{NaOH}$. Salinity tolerance was determined in YP-SW broth prepared with $0,5,15,20,40,75$ or $100 \%$ filtered sea water. Salt requirement and tolerance were tested in modified ASW supplemented with $0 \cdot 4 \%$ yeast extract and with $\mathrm{NaCl}$ added at $0,1,2,5,7 \cdot 5,10$ or $15 \%$. Anaerobic growth was examined by using the Oxoid anaerobic system. Acid production from carbohydrates was determined by using API $50 \mathrm{CH}$ strips (bioMérieux) and cells grown on a medium composed of $50 \% \mathrm{CHB} / \mathrm{E}$ medium (bioMérieux) with $0.075 \% \mathrm{CaCl}_{2} \cdot 2 \mathrm{H}_{2} \mathrm{O}, 1.875 \% \mathrm{NaCl}$ and $0.375 \% \mathrm{MgCl}_{2}$. Carbohydrate assimilation was determined using API $50 \mathrm{CH}$ strips and cells grown on ASW supplemented with $0.05 \%$ yeast extract. Fermentation of $(+)$-D-glucose, Dgalactose, raffinose, sucrose, maltose, (-)-D-mannitol, Dsorbitol, inositol and dextran and hydrolysis of alginate, chitin and Tween 20 were tested according to Baumann \& Baumann (1981). Catalase, oxidase, alkaline phosphatase and lecithinase activities, nitrate reduction, indole production, $\mathrm{H}_{2} \mathrm{~S}$ generation from thiosulfate or cysteine, and hydrolysis of cellulose, starch and gelatin were tested according to Smibert \& Krieg (1994). $\beta$-Galactosidase activity and casein hydrolysis were examined according to Gosink et al. (1998) and Norris et al. (1985), respectively. Haemolytic activity was investigated using defibrinated rabbit blood ( $5 \%$, v/v) agar prepared with blood agar base (BBL). Degradation of dead yeast cells was tested on VY/2 agar prepared with $20 \%$ filtered sea water (Reichenbach, 1989). DNA hydrolysis was examined by culturing cells in YP-SW broth supplemented with $100 \mu \mathrm{g}$ salmon sperm DNA $\mathrm{ml}^{-1}$ for $36 \mathrm{~h}$ and monitoring DNA degradation by agarose-gel electrophoresis. Susceptibility to antibiotics was tested by the disc-diffusion plate method on YP-SW agar. Isoprenoid quinone analysis was performed by the HPLC method (Collins, 1994) using menaquinones extracted from Cytophaga lytica (Nakagawa \& Yamasato, 1993) and Sphingobacterium heparinum (Steyn et al., 1998) as the MK-6 and MK-7 references, respectively. The whole-cell fatty acid methyl ester profile was determined by using the MIDI Sherlock Microbial Identification system (Microbial ID) with cells of UST20020801 $1^{\mathrm{T}}$ grown at $10^{\circ} \mathrm{C}$ for 5 days in marine agar 2216 (Difco). Genomic DNA was extracted by using the Invisorb spin tissue kit (Invitek) and DNA base composition was determined by the HPLC method (Johnson, 1985), calibrated and calculated according to Mesbah et al. (1989). The 16S rRNA gene was amplified by using primer pair 27F (5'-AGAGTTTGATCCTGGCTCAG-3') and 1525R ( $5^{\prime}$-AAGGAGTGWTCCARCC-3') (Lane, 1991) with Taq polymerase (Promega) and the amplicon was purified with the ConceRT-PCR purification kit (Life Technologies), treated with the ABI PRISM BigDye Terminator cycle sequencing ready reaction kit version 3.0 and sequenced using an Applied Biosystems 3100 automated DNA sequencer. The sequences were aligned and assembled before being compared with sequences from GenBank using the programs BLASTN (Altschul et al., 1997) and WU-BLAST 2.0 (http://blast.wustl.edu). The sequences of UST $20020801^{\mathrm{T}}$ and related species were then aligned by using CLUSTAL_X (Thompson et al., 1997) and the alignment file was edited with the BIOEDIT sequence alignment editor V5.0.9 (http://www.mbio.ncsu.edu/BioEdit/bioedit.html)

Table 1. Phenotypic features of strain UST20020801 ${ }^{\top}$

This strain cannot form acid from or utilize glucose, dextran, glycerol, erythritol, D-arabinose, L-arabinose, D-ribose, D-xylose, L-xylose, D-adonitol, methyl $\beta$-D-xylopyranoside, D-galactose, Dglucose, D-fructose, D-mannose, L-sorbose, L-rhamnose, dulcitol, inositol, D-mannitol, D-sorbitol, methyl $\alpha$-D-mannopyranoside, methyl $\alpha$-D-glucopyranoside, $N$-acetylglucosamine, amygdalin, arbutin, aesculin, ferric citrate, salicin, D-cellobiose, D-maltose, Dlactose, D-melibiose, sucrose, D-trehalose, D-melezitose, D-raffinose, glycogen, xylitol, gentiobiose, D-turanose, D-lyxose, D-tagatose, D-fucose, L-fucose, D-arabitol, L-arabitol or potassium gluconate. It is unable to ferment glucose, D-galactose, raffinose, sucrose, maltose, (-)-D-mannitol, D-sorbitol, inositol or dextran.

\begin{tabular}{|lc|}
\hline Characteristic & UST20020801 \\
\hline Salinity range (\%) & $1 \cdot 0-7 \cdot 5$ \\
NaCl & $15-100$ \\
Sea water & + \\
Oxidase & + \\
Catalase & - \\
Nitrate reduction & + \\
Alkaline phosphatase & - \\
$\beta$-Galactosidase & - \\
Lecithinase & \\
Utilization of: & + \\
Tween 20 & + \\
Gelatin & - \\
Alginate & - \\
Agar & - \\
Casein & - \\
Cellulose & - \\
Chitin & - \\
DNA & - \\
Starch & - \\
Production of: & - \\
$\mathrm{H}_{2} \mathrm{~S}$ & - \\
Indole & - \\
Hydrolysis of dead yeast cells & - \\
Haemolysis in rabbit blood agar & - \\
\hline
\end{tabular}


with gaps and missing nucleotide positions removed. Evolutionary distances of 1139 aligned positions were computed using the Kimura two-parameter model (Kimura, 1980) and the phylogenetic tree was generated by TREECON v1.3b (Van de Peer \& De Wachter, 1994) using the neighbour-joining method (Saitou \& Nei, 1987) and evaluated by bootstrap analyses (Felsenstein, 1985) based on 300 resamplings. Maximum-parsimony analysis was conducted by using MEGA version 2.1 (Kumar et al., 2001).

Morphological properties of UST20020801 ${ }^{\mathrm{T}}$ are listed in the genus and species descriptions. A photograph of its colony morphology and phase-contrast and scanning electron micrographs are available as supplementary material in IJSEM Online (Figs a-e). Table 1 lists all the physiological and biochemical properties that were analysed. The more conserved characteristics of this strain were also investigated. The isoprenoid quinone of UST20020801 ${ }^{\mathrm{T}}$ is MK-6, a major respiratory quinone detected in members of the family Flavobacteriaceae (Bernardet et al., 2002).

The fatty acid profile of UST20020801 ${ }^{\mathrm{T}}$ and those of phylogenetically related members of the family Cryomorphaceae are given in Table 2. UST20020801 ${ }^{\mathrm{T}}$ contained a high percentage of the following branched-chain fatty acids $(77 \cdot 8 \%$ total fatty acids): $i 15: 1 \mathrm{G}, \mathrm{i} 15: 1,3-\mathrm{OH}$ i17:0, i17: $1 \omega 9 c$ and $3-\mathrm{OH}$ i15:1. The fatty acid profile of UST20020801 ${ }^{\mathrm{T}}$ differed significantly from those of other members of the family Cryomorphaceae. The strain possessed several unique fatty acids: i15:1G, i17: $1 \omega 9 c, 2-\mathrm{OH} 15: 0$, $15: 1 \omega 6 c$ and three unknown fatty acids with equivalent chain-lengths of $11.543,13.565$ and $16 \cdot 582$. Strain UST20020801 ${ }^{\mathrm{T}}$ had the highest level of $3-\mathrm{OH}$ i17:0 among members of the family Cryomorphaceae. Compared with other members of the family Cryomorphaceae,
UST20020801 ${ }^{\mathrm{T}}$ most resembled Cryomorpha ignava $1-22^{\mathrm{T}}$ in terms of its relatively low content of straight-chain fatty acids and relatively high content of branched-chain hydroxy fatty acids.

The 16S rRNA gene sequence of strain UST20020801 ${ }^{\mathrm{T}}$ (1482 nt positions) showed $92 \cdot 4 \%$ similarity to an uncultured clone, ARKIA-105 (GenBank/EMBL/DDBJ accession no. AF468278), isolated from Arctic pack ice located at Northern Fram Strait (Brinkmeyer et al., 2003), and 87.5\% similarity to 'Microscilla aggregans var. catalatica' strain IFO 15977, which has been reclassified as the type strain of Crocinitomix catalasitica (Bowman et al., 2003). The $16 \mathrm{~S}$ rRNA gene sequences of relatives of Crocinitomix catalasitica and other members of the phylum 'Bacteroidetes' were retrieved from GenBank. Phylogenetic analysis showed that strain UST20020801 ${ }^{\mathrm{T}}$ and clone ARKIA-105 formed a distinct lineage within the family Cryomorphaceae, linked to Cryomorpha ignava $1-22^{\mathrm{T}}$ with bootstrap support of $85 \%$ by the neighbour-joining method (Fig. 1) and $62 \%$ by maximum-parsimony analysis (data not shown). Sequence similarities to other members of the family Cryomorphaceae were less than $90 \%$ (Cryomorpha ignava $1-22^{\mathrm{T}}, 87 \cdot 2 \%$; Brumimicrobium glaciale IC156 ${ }^{\mathrm{T}}, 86 \cdot 1 \%$ ), indicating that strain UST20020801 ${ }^{\mathrm{T}}$ is distantly related to them at the genus level. Phenotypically, strain UST20020801 ${ }^{\mathrm{T}}$ displayed some traits in common with members of the family Cryomorphaceae: rod- to filamentous-shaped cells; possession of carotenoid pigments; the ability to perform aerobic respiration; the requirement of sea-salts and complex organic compounds such as yeast extract or peptone for growth; no acid production from carbohydrate; and an inability to utilize starch, casein or chitin. The DNA G +C content of UST20020801 ${ }^{\mathrm{T}}$ was $39 \cdot 6 \pm 0 \cdot 5 \mathrm{~mol} \%$, which is within the range of values for members of the family

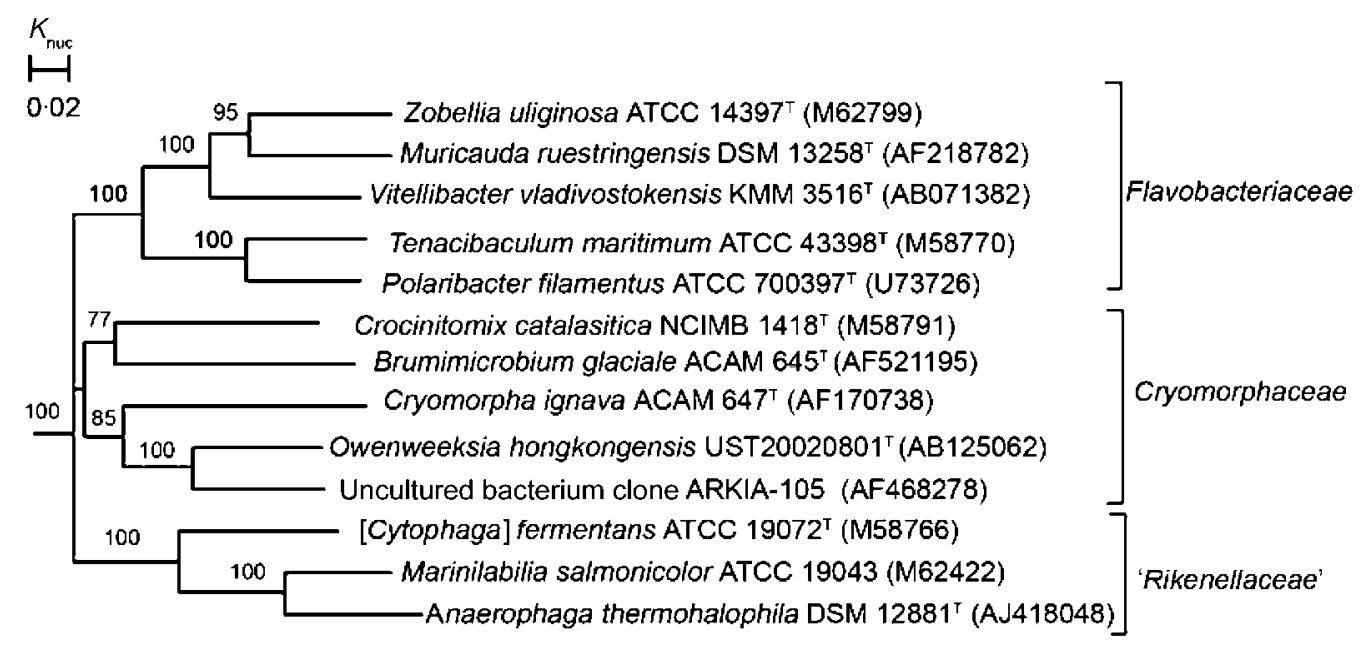

Fig. 1. Phylogenetic relationship of strain UST20020801' and related taxa within the phylum 'Bacteroidetes' based on $16 \mathrm{~S}$ rRNA gene sequences. The tree was created by using the neighbour-joining method and the numbers at the nodes represent levels of bootstrap support (as percentages) from 300 resampled datasets. Escherichia coli ATCC $11775^{\top}$ (GenBank/EMBL/ DDBJ accession no. X80725) was used as the outgroup. Bar, 0.02 nt substitutions per position. 
Table 2. Whole-cell fatty acid profiles of strain UST20020801 ${ }^{\top}$ and the members of the family Cryomorphaceae

Strains: 1, UST20020801 $1^{\mathrm{T}}$; 2, Brumimicrobium glaciale $\mathrm{IC} 156^{\mathrm{T}} ; 3$, Cryomorpha ignava $1-22^{\mathrm{T}} ; 4$, Crocinitomix catalasitica NCIMB $1418^{\mathrm{T}}$. Values given are percentages of total fatty acids. Fatty acids are designated as follows: total number of carbon atoms: number of double bonds, followed by the position of the double bond from the aliphatic end of the molecule. Prefixes i, a and OH represent iso-branched, anteiso-branched and hydroxy fatty acids, respectively. The suffix $c$ represents a cis isomer. ECL, equivalent chain-length; TR, less than $0 \cdot 1 \%$. Data for UST20020801 ${ }^{\mathrm{T}}$ are from this study; data for strains $2-4$ are from Bowman et al. (2003).

\begin{tabular}{|c|c|c|c|c|}
\hline Fatty acid & 1 & 2 & 3 & 4 \\
\hline $13: 0$ & - & 0.5 & - & - \\
\hline $14: 0$ & - & $1 \cdot 5$ & - & $0 \cdot 3$ \\
\hline $15: 0$ & - & $2 \cdot 9$ & $0 \cdot 8$ & $29 \cdot 3$ \\
\hline $16: 0$ & $0 \cdot 3$ & $1 \cdot 9$ & $0 \cdot 9$ & $1 \cdot 8$ \\
\hline $18: 0$ & - & $0 \cdot 3$ & - & - \\
\hline i10 : 0 & $\mathrm{TR}$ & - & - & - \\
\hline i11:0 & $0 \cdot 3$ & - & - & - \\
\hline i13 : 0 & - & $5 \cdot 6$ & - & - \\
\hline a13:0 & - & $\mathrm{TR}$ & - & - \\
\hline i14: 0 & - & $0 \cdot 8$ & $13 \cdot 8$ & - \\
\hline i15: 0 & $18 \cdot 7$ & $36 \cdot 4$ & $7 \cdot 8$ & $36 \cdot 3$ \\
\hline $\mathrm{i} 15: 1 \mathrm{G}$ & $28 \cdot 0$ & - & - & - \\
\hline a15:0 & - & $\mathrm{TR}$ & $5 \cdot 8$ & - \\
\hline i16: 0 & $\mathrm{TR}$ & $0 \cdot 6$ & $7 \cdot 8$ & $0 \cdot 4$ \\
\hline a16:0 & $0 \cdot 2$ & - & - & - \\
\hline $\mathrm{i} 14: 1 \omega 9 c$ & - & $0 \cdot 4$ & $6 \cdot 8$ & $0 \cdot 7$ \\
\hline $\mathrm{i} 15: 1 \omega 10 c$ & - & - & $7 \cdot 1$ & $10 \cdot 9$ \\
\hline $\mathrm{a} 15: 1 \omega 10 c$ & - & 45 & $8 \cdot 2$ & - \\
\hline $\mathrm{i} 16: 1 \omega 6 c$ & - & $0 \cdot 5$ & - & - \\
\hline $\mathrm{i} 16: 1 \omega 11 c$ & - & - & $2 \cdot 9$ & $0 \cdot 3$ \\
\hline $\mathrm{i} 17: 1 \omega 9 c$ & $7 \cdot 3$ & - & - & - \\
\hline $\mathrm{i} 17: 1 \omega 12 c$ & - & - & - & $0 \cdot 7$ \\
\hline $\mathrm{i} 17: 1 \omega 13 c$ & - & - & - & $0 \cdot 2$ \\
\hline a $17: 1 \omega 13 c$ & - & - & - & $\mathrm{TR}$ \\
\hline $15: 1 \omega 4 c$ & - & - & - & TR \\
\hline $15: 1 \omega 6 c$ & $1 \cdot 3$ & - & - & - \\
\hline $15: 1 \omega 8 c$ & - & $1 \cdot 4$ & - & - \\
\hline $15: 1 \omega 11 c$ & - & - & - & $8 \cdot 3$ \\
\hline $16: 1 \omega 5 c$ & - & - & - & $\mathrm{TR}$ \\
\hline $16: 1 \omega 7 c$ & ND & $1 \cdot 5$ & - & - \\
\hline $16: 1 \omega 12 c$ & - & - & - & $4 \cdot 4$ \\
\hline $17: 1 \omega 13 c$ & - & - & - & $2 \cdot 1$ \\
\hline $18: 1 \omega 5 c$ & $0 \cdot 3$ & - & - & - \\
\hline $18: 1 \omega 7 c$ & - & $0 \cdot 3$ & - & - \\
\hline $18: 1 \omega 9 c$ & - & $0 \cdot 4$ & - & - \\
\hline $2-\mathrm{OH}$ i14:0 & - & - & $6 \cdot 7$ & - \\
\hline 2-OH $15: 0$ & $3 \cdot 0$ & - & - & - \\
\hline $2-\mathrm{OH}$ a15:0 & - & - & $18 \cdot 4$ & - \\
\hline $3-\mathrm{OH} 15: 0$ & $1 \cdot 0$ & - & - & TR \\
\hline 3-OH i15:0 & $4 \cdot 9$ & - & - & $1 \cdot 0$ \\
\hline $3-\mathrm{OH} 16: 0$ & - & - & $2 \cdot 9$ & - \\
\hline $3-\mathrm{OH}$ i16:0 & $0 \cdot 2$ & - & $6 \cdot 8$ & TR \\
\hline 3-OH 17:0 & $1 \cdot 2$ & - & - & $\mathrm{TR}$ \\
\hline $3-\mathrm{OH}$ i17:0 & $18 \cdot 1$ & - & - & $3 \cdot 3$ \\
\hline 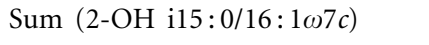 & $10 \cdot 0$ & $1 \cdot 5$ & $1 \cdot 6$ & - \\
\hline Unknown fatty acid, ECL $11 \cdot 543$ & $0 \cdot 4$ & - & - & - \\
\hline Unknown fatty acid, ECL $13 \cdot 565$ & $4 \cdot 5$ & - & - & - \\
\hline Unknown fatty acid, ECL $16 \cdot 582$ & $0 \cdot 2$ & - & - & - \\
\hline
\end{tabular}


Cryomorphaceae (35-40 mol\%) and close to that of its nearest phylogenetic relative, Cryomorpha ignava (36$37 \mathrm{~mol} \%)$. Strain UST20020801 ${ }^{\mathrm{T}}$ differed from other members of the family Cryomorphaceae by possessing oxidase and gelatinase activities and growing well at $37^{\circ} \mathrm{C}$. Strain UST20020801 $1^{\mathrm{T}}$ can be distinguished from related genera of the 'Bacteroidetes' by several phenotypic tests (Table 3). On the basis of all characteristics described above, it is proposed that strain UST20020801 ${ }^{\mathrm{T}}$ should be placed in a new genus as a representative of a novel species, Owenweeksia hongkongensis gen. nov., sp. nov.

\section{Description of Owenweeksia gen. nov.}

Owenweeksia (Ow.en.week'si.a. N.L. fem. n. Owenweeksia bacterial genus named after Owen B. Weeks, who did a lot of work in the 1950s, 1960s and 1970s on Flavobacterium, Cytophaga and related species).

Cells are Gram-negative, halophilic, non-flagellated, motile, flexible, short rods with slightly tapered ends. Cells do not form spores and are strictly aerobic heterotrophs requiring $\mathrm{Na}^{+}, \mathrm{Mg}^{2+}$, sea-salts and either yeast extract or peptone for growth. Cells contain oxidase, catalase and alkaline phosphatase. Cellular fatty acids include large amounts of branched-chain fatty acids: i15:0G, i15:0, 3-OH i17:0, $2-\mathrm{OH}$ i15:0/16:1 $1 \omega 7 c$, i17: $1 \omega 9 c, 3-\mathrm{OH}$ i15:0 and an unknown fatty acid of equivalent chain-length 13.565. The major respiratory quinone is MK-6. Phylogenetically, the genus Owenweeksia is a member of the family Cryomorphaceae in the phylum 'Bacteroidetes'.
The type species is Owenweeksia hongkongensis.

\section{Description of Owenweeksia hongkongensis sp. nov.}

Owenweeksia hongkongensis (hong.kong.en'sis. N.L. fem. adj. hongkongensis pertaining to Hong Kong, S. A. R., P. R. China).

Exhibits the following properties in addition to those given in the genus description. Cells are $0 \cdot 3-0 \cdot 5 \mu \mathrm{m}$ in diameter and $0 \cdot 5-4 \cdot 0 \mu \mathrm{m}$ in length. Filamentous cells detected in cultures supplemented with $0 \cdot 1 \%$ Tween 20 . In YP-SW broth incubated at $4{ }^{\circ} \mathrm{C}$ or room temperature for 1 week, cells with one end, both ends or the whole body greatly enlarged are observed. Colonies are orange, smooth, convex, glistening and translucent with an entire margin. Growth occurs at $4-37^{\circ} \mathrm{C}$ and $\mathrm{pH} 5 \cdot 2-9 \cdot 0$ with optimum growth at $25-33^{\circ} \mathrm{C}$ and $\mathrm{pH} 6 \cdot 0-8 \cdot 0$. Cells possess carotenoid pigments with maximum absorption at $470 \mathrm{~nm}$ and two shoulder peaks around $448 \mathrm{~nm}$ and $501 \mathrm{~nm}$. Physiological and biochemical properties are listed in Table 1 . The fatty acid profile is given in Table 2 . Sensitive to ampicillin $(10 \mu \mathrm{g})$, chloramphenicol $(30 \mu \mathrm{g})$, erythromycin $(10 \mu \mathrm{g})$, penicillin $\mathrm{G}(2 \mathrm{U})$, rifampicin $(10 \mu \mathrm{g})$, streptomycin $(10 \mu \mathrm{g})$, tetracycline $(30 \mu \mathrm{g})$ and polymyxin $\mathrm{B}(300 \mathrm{U})$, but resistant to kanamycin $(10 \mu \mathrm{g})$, gentamicin sulfate $(10 \mu \mathrm{g})$ and spectinomycin $(10 \mu \mathrm{g})$.

The type strain is UST20020801 ${ }^{\mathrm{T}}\left(=\mathrm{NRRL} \mathrm{B}-23963^{\mathrm{T}}=\right.$ JCM $12287^{\mathrm{T}}$ ), which was isolated from a sea-water sample

Table 3. Characteristics that differentiate strain UST20020801 ${ }^{\top}$ from other related members in the phylum 'Bacteroidetes'

Strain/taxa:1, Brumimicrobium glaciale; 2, Cryomorpha ignava; 3, Crocinitomix catalasitica; 4, the genus Cellulophaga; 5, [Cytophaga] marinoflava; 6, Croceibacter atlanticus; 7, Tenacibaculum maritimum; 8, [Cytophaga] latercula; 9, Muricauda ruestringensis; 10, Tenacibaculum amylolyticum; 11, UST20020801 ${ }^{\mathrm{T}} ; 12$, Vitellibacter vladivostokensis; 13, Arenibacter latericius; 14, the genus Zobellia; 15, Tenacibaculum mesophilum. Data are from Bowman et al. (2003), Johansen et al. (1999), Reichenbach (1989), Cho \& Giovannoni (2003), Suzuki et al. (2001), Bruns et al. (2001), Nedashkovskaya et al. (2003), Ivanova et al. (2001), Barbeyron et al. (2001) and this study. ND, Not determined; +, positive; -, negative; V, variable; W, weak; A, strict aerobe; F, facultative anaerobe, O, orange; R, red; Y, yellow.

\begin{tabular}{|c|c|c|c|c|c|c|c|c|c|c|c|c|c|c|c|}
\hline Characteristic & 1 & 2 & 3 & 4 & 5 & 6 & 7 & 8 & 9 & 10 & 11 & 12 & 13 & 14 & 15 \\
\hline Oxidase/catalase & $-1+$ & $-1+$ & $-1+$ & $\mathrm{V} /+$ & $+1+$ & $-1+$ & $+1+$ & $+1-$ & $+1-$ & $+1+$ & $+1+$ & $+1+$ & $+1+$ & $+1+$ & $+1+$ \\
\hline Colour of cell mass & $\mathrm{O}$ & $\mathrm{O}$ & $\mathrm{Y}$ & $\mathrm{O}-\mathrm{Y}$ & $\mathrm{Y}$ & $\mathrm{O}$ & $\mathrm{Y}$ & O-R & $\mathrm{Y}$ & $\mathrm{Y}$ & $\mathrm{O}$ & $\mathrm{Y}-\mathrm{O}$ & $\mathrm{O}$ & $\mathrm{Y}-\mathrm{O}$ & $\mathrm{Y}$ \\
\hline Flexirubin reaction & - & - & - & - & - & - & - & - & - & - & - & + & - & + & - \\
\hline Gliding motility & + & - & + & + & + & - & + & - & - & + & + & - & - & + & + \\
\hline Phosphatase & + & - & + & ND & ND & ND & ND & $\mathrm{ND}$ & ND & ND & + & + & + & ND & ND \\
\hline \multicolumn{16}{|l|}{ Hydrolysis of: } \\
\hline Agar & - & - & - & + & - & - & - & + & - & - & - & - & - & + & - \\
\hline Gelatin & - & - & - & $\mathrm{V}$ & $\mathrm{ND}$ & + & - & + & - & + & + & + & - & + & + \\
\hline Starch & - & - & - & + & + & + & - & - & - & + & - & - & - & $\mathrm{V}$ & - \\
\hline
\end{tabular}


collected in Port Shelter, Hong Kong, S. A. R., P. R. China. DNA G + C content of the type strain is $39 \cdot 6 \pm 0 \cdot 5 \mathrm{~mol} \%$.

\section{Acknowledgements}

We sincerely thank Professor Dr Hans G. Trüper and Dr Alejandro Rooney for valuable suggestions in the etymology of the new bacterial name. We thank Dr Yoshimi Benno for deposition of our strain in the Japanese Collection of Microorganisms and Dr Alejandro Rooney for supply of bacterial strains and deposition of our strain in the Agricultural Research Service Culture Collection. We also thank Natalie of CUHK for generous help on fatty acid analysis of our strain. This work was supported by CAG group research project CA00/ 01.SC01 and HKUST grant CMI03/04.SC03.

\section{References}

Altschul, S. F., Madden, T. L., Schaffer, A. A., Zhang, J., Zhang, Z., Miller, W. \& Lipman, D. J. (1997). Gapped BLAST and PSI-BLAST: a new generation of protein database search programs. Nucleic Acids Res 25, 3389-3402.

Barbeyron, T., L'Haridon, S., Corre, E., Kloareg, B. \& Potin, P. (2001). Zobellia galactanovorans gen. nov., sp. nov., a marine species of Flavobacteriaceae isolated from a red alga, and classification of [Cytophaga] uliginosa (ZoBell and Upham 1944) Reichenbach 1989 as Zobellia uliginosa gen. nov., comb. nov. Int J Syst Evol Microbiol 51, 985-997.

Baumann, P. \& Baumann, L. (1981). The marine Gram-negative eubacteria: genera Photobacterium, Beneckea, Alteromonas, Pseudomonas and Alcaligenes. In The Prokaryotes, vol. 1, pp. 1302-1331. Edited by M. P. Starr, H. Stolp, H. G. Trüper, A. Balows \& H. Schlegel. Berlin: Springer.

Bernardet, J.-F., Nakagawa, Y. \& Holmes, B. (2002). Proposed minimal standards for describing new taxa of the family Flavobacteriaceae and emended description of the family. Int J Syst Evol Microbiol 52, 1049-1070.

Bowman, J. P., Mancuso Nichols, C. \& Gibson, J. A. E. (2003). Algoriphagus ratkowskyi gen. nov., sp. nov., Brumimicrobium glaciale gen. nov., sp. nov., Cryomorpha ignava gen. nov., sp. nov. and Crocinitomix catalasitica gen. nov., sp. nov., novel flavobacteria isolated from various polar habitats. Int J Syst Evol Microbiol 53, 1343-1355.

Brinkmeyer, R., Knittel, K., Jürgens, J., Weyland, H., Amann, R. \& Helmke, E. (2003). Diversity and structure of bacterial communities in Arctic versus Antarctic pack ice. Appl Environ Microbiol 69, 6610-6619.

Bruns, A., Rohde, M. \& Berthe-Corti, L. (2001). Muricauda ruestringensis gen. nov., sp. nov., a facultatively anaerobic, appendaged bacterium from German North Sea intertidal sediment. Int J Syst Evol Microbiol 51, 1997-2006.

Cho, J. C. \& Giovannoni, S. J. (2003). Croceibacter atlanticus gen. nov., sp. nov., a novel marine bacterium in the family Flavobacteriaceae. Syst Appl Microbiol 26, 76-83.

Collins, M. D. (1994). Isoprenoid quinones. In Chemical Methods in Prokaryotic Systematics, pp. 265-310. Edited by M. Goodfellow \& A. G. O'Donnell. Chichester: Wiley.

Collins, C. H., Lyne, P. M. \& Grange, J. M. (1989). Collins and Lyne's Microbiological Methods. London/Boston: Butterworths.

Cottrell, M. T. \& Kirchman, D. L. (2000). Natural assemblages of marine proteobacteria and members of the Cytophaga-Flavobacter cluster consuming low- and high-molecular weight dissolved organic matter. Appl Environ Microbiol 66, 1692-1697.
Fautz, E. \& Reichenbach, H. (1980). A simple test for flexirubin-type pigments. FEMS Microbiol Lett 8, 87-91.

Felsenstein, J. (1985). Confidence limits on phylogenies: an approach using the bootstrap. Evolution 39, 783-791.

Gosink, J. J., Woese, C. R. \& Staley, J. T. (1998). Polaribacter gen. nov., with three new species, $P$. irgensii sp. nov., $P$. franzmannii sp. nov. and $P$. filamentus sp. nov., gas vacuolate polar marine bacteria of the Cytophaga-Flavobacterium-Bacteroides group and reclassification of 'Flectobacillus glomeratus' as Polaribacter glomeratus comb. nov. Int J Syst Bacteriol 48, 223-235.

Ivanova, E. P., Nedashkovskaya, O. I., Chun, J. \& 7 other authors (2001). Arenibacter gen. nov., new genus of the family Flavobacteriaceae and description of a new species, Arenibacter latericius sp. nov. Int J Syst Evol Microbiol 51, 1987-1995.

Johansen, J. E., Nielsen, P. \& Sjøholm, C. (1999). Description of Cellulophaga baltica gen. nov., sp. nov. and Cellulophaga fucicola gen. nov., sp. nov. and reclassification of [Cytophaga] lytica to Cellulophaga lytica gen. nov., comb. nov. Int J Syst Bacteriol 49, 1231-1240. Johnson, J. L. (1985). Determination of DNA base composition. Methods Microbiol 18, 1-31.

Kimura, M. (1980). A simple method for estimating evolutionary rates of base substitutions through comparative studies of nucleotide sequences. J Mol Evol 16, 111-120.

Kumar, S., Tamura, K., Jakobsen, I. B. \& Nei, M. (2001). MEGA2: molecular evolutionary genetics analysis software. Bioinformatics $\mathbf{1 7}$, 1244-1245.

Lane, D. J. (1991). 16S/23S rRNA sequencing. In Nucleic Acid Techniques in Bacterial Systematics, pp. 115-175. Edited by E. Stackebrandt \& M. Goodfellow. Chichester: John Wiley.

Lewin, R. A. \& Lounsbery, D. M. (1969). Isolation, cultivation and characterization of flexibacteria. J Gen Microbiol 58, 145-170.

Mesbah, M., Premachandran, U. \& Whitman, W. B. (1989). Precise measurement of the $\mathrm{G}+\mathrm{C}$ content of deoxyribonucleic acid by highperformance liquid chromatography. Int J Syst Bacteriol 39, 159-167.

Nakagawa, Y. \& Yamasato, K. (1993). Phylogenetic diversity of the genus Cytophaga revealed by $16 \mathrm{~S}$ rRNA sequencing and menaquinone analysis. J Gen Microbiol 139, 1155-1161.

Nedashkovskaya, O. I., Suzuki, M., Vysotskii, M. V. \& Mikhailov, V. V. (2003). Vitellibacter vladivostokensis gen. nov., sp. nov., a new member of the phylum Cytophaga-Flavobacterium-Bacteroides. Int J Syst Evol Microbiol 53, 1281-1286.

Norris, J. R., Ribbons, D. W. \& Varma, A. K. (editors) (1985). Methods in Microbiology, vol. 18. London: Academic Press.

Reichenbach, H. (1989). Family 1. Cytophagaceae Stanier 1940, $630^{\mathrm{AL}}$ emend. In Bergey's Manual of Systematic Bacteriology, vol. 3, pp. 2015-2082. Edited by J. T. Staley, M. P. Bryant, N. Pfennig \& J. G. Holt. Baltimore: Williams \& Wilkins.

Robinson, D. G., Ehlers, U., Herken, R., Herrmann, B., Mayer, F. \& Schürmann, F.-W. (1987). Methods for SEM. In Methods of Preparation for Electron Microscopy: an Introduction for the Biomedical Sciences, pp. 145-165. Berlin: Springer.

Saitou, N. \& Nei, M. (1987). The neighbor-joining method: a new method for reconstructing phylogenetic trees. Mol Biol Evol 4, 406-425.

Smibert, R. M. \& Krieg, N. R. (1994). Phenotypic characterization. In Methods for General and Molecular Bacteriology, pp. 607-654. Edited by P. Gerhardt, R. G. E. Murray, W. A. Wood \& N. R. Krieg. Washington, DC: American Society for Microbiology

Steyn, P. L., Segers, P., Vancanneyt, M., Sandra, P., Kersters, K. \& Joubert, J. J. (1998). Classification of heparinolytic bacteria into a new genus, Pedobacter, comprising four species: Pedobacter heparinus comb. nov., Pedobacter piscium comb. nov., Pedobacter africanus 
sp. nov. and Pedobacter saltans sp. nov. Proposal of the family Sphingobacteriaceae. Int J Syst Bacteriol 48, 165-177.

Suzuki, M., Nakagawa, Y., Harayama, S. \& Yamamoto, S. (2001). Phylogenetic analysis and taxonomic study of marine Cytophaga-like bacteria: proposal for Tenacibaculum gen. nov. with Tenacibaculum maritimum comb. nov. and Tenacibaculum ovolyticum comb. nov., and description of Tenacibaculum mesophilum sp. nov. and Tenacibaculum amylolyticum sp. nov. Int J Syst Evol Microbiol 51, 1639-1652.
Thompson, J. D., Gibson, T. J., Plewniak, F., Jeanmougin, F. \& Higgins, D. G. (1997). The CLUSTAL_X windows interface: flexible strategies for multiple sequence alignment aided by quality analysis tools. Nucleic Acids Res 25, 4876-4882.

Van de Peer, Y. \& De Wachter, R. (1994). TREECON for Windows: a software package for the construction and drawing of evolutionary trees for the Microsoft Windows environment. Comput Appl Biosci 10, 569-570. 